C.

5B 691 2य6

YL 04333

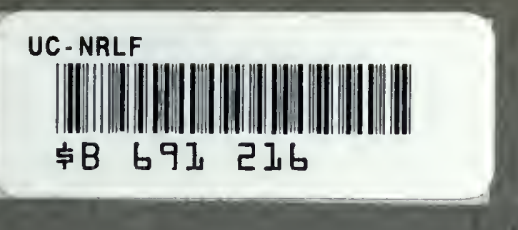

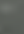




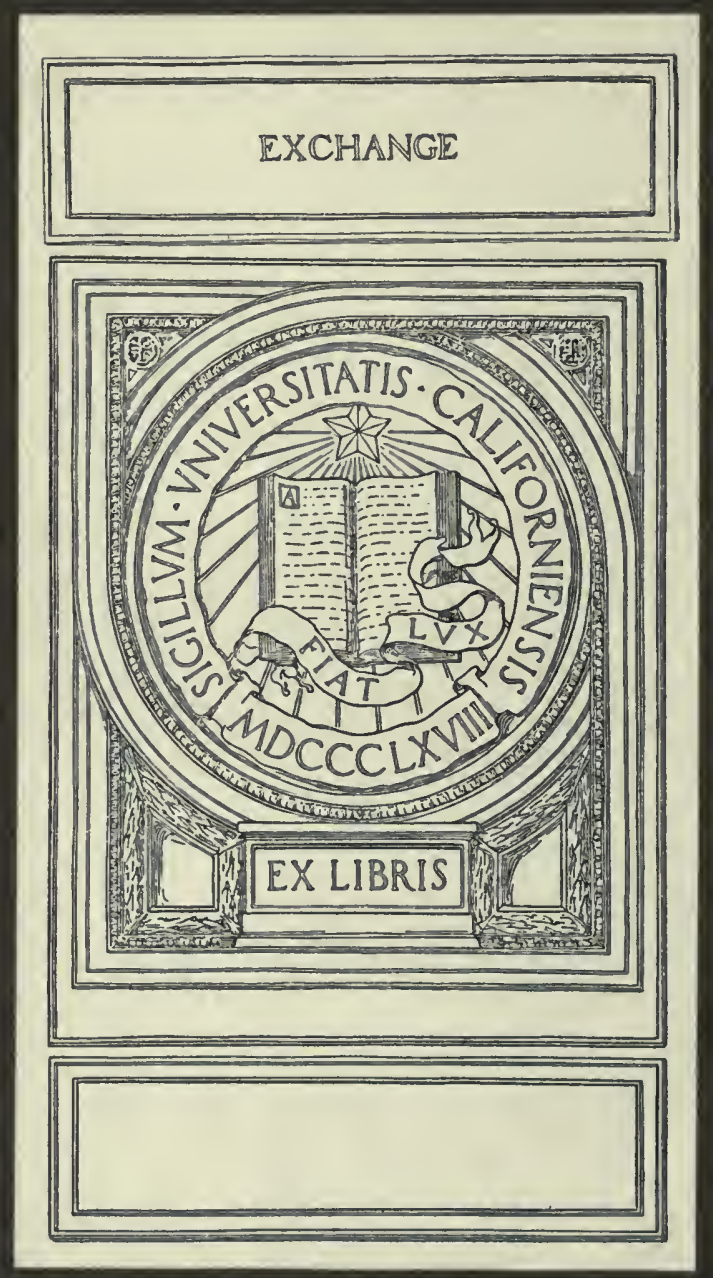




\section{Fishways in the Inland Waters of British Columbia}

By ARTHUR V. WHITE

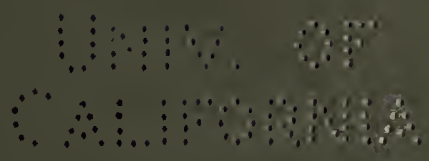

Commission of Conservation Canada 


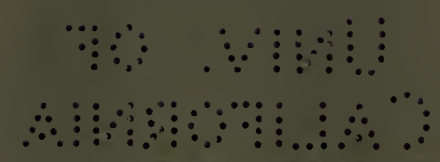

Digitized by the Internet Archive in 2008 with funding from Microsoft Corporation 
COM MISSION OF CONSERVATION C A N A D A

\title{
Fishways in the Inland Waters of British Columbia
}

\author{
BY \\ ARTHUR V. WHITE \\ Consulting Engineer \\ Commission of Conservation
}

COMMITTEE ON FISHERIES

DR. C. C. Jones, Chairman

Hon. A. E. Arsenault

Mr. J. P. BABCOCK

Hon. O. T. Daniels

Hon. G. H. Ferguson
Hon. A. B. Hudson

Dr. Howard Murray

Hon. T. D. Pattulizo

DR. J. W. ROBERTSON

Hon. E. A. Smith 


\section{Commission of Conservation}

Constituted under "The Conservation Act," 8-9 Edward VII., Chap. 27, 1909, and amending Acts, 9-10 Edward VII, Chap. 42, 1910, and 3-4 George V, Chap. 12, 1913.

Chairman:

Sir Cimford Sifton, K.C.M.G.

Members:

DR. Howard MurRay, Dalhousie University, Halifax, N.S.

DR. CECIL C. JONES, Chancellor, University of New Brunswick, Fredericton, N.B.

Mr. William B. SNowball, Chatham, N.B.

Hon. HeNRI S. BELAND, M.D., M.P., St. Joseph-de-Beauce, Que.

Dr. FraAX D. ADAMS, Dean, Faculty of Applied Science, McGill University, Mơntreal, Qué.: :?:

Mgr. Charles P. Chopútitre, St. Hyacinthe, Que., Professor, Seminary of $\therefore$ St. Hyarinthe:and Membet of Faculty, Laval University.

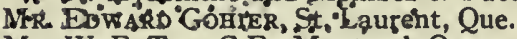

Mr. W. F. TYE, C.E., Montreal, Que.

Dr. James W. Robertson, C.M.G., Ottawa, Ont.

Hon. Senator William Cameron Edwards, Ottawa, Ont.

Mr. Charles A. McCool, Pembroke, Ont.

Sir EDMUND B. OSLER, M.P., Toronto, Ont.

Mr. John F. MACKay, Business Manager, The Globe, Toronto, Ont.

DR. B. E. FERnOw, Faculty of Forestry, University of Toronto, Toronto, Ont.

Dr. GeORGe Bryce, University of Manitoba, Winnipeg, Man.

Dr. WIILIAM J. RuTHERFORD, Member of Faculty, University of Saskatchewan, Saskatoon, Sask.

Dr. Henry M. TORY, President, University of Alberta, Edmonton, Alta.

Mr. John Pease Babcock, Victoria, B.C.

Members ex-officio:

Hon. T. A. CRERAR, Minister of Agriculture, Ottawa.

Hon. Arthur Meighen, Minister of the Interior, Ottawa.

Hon. Martin Burrel, Minister of Mines, Ottawa.

Hon. Aubin E. Arsenault, Premier, Prince Edward Island, Charlottetown, P.E.I.

Hon. Orlando T. Daniels, Attorney-General, Nova-Scotia.

HoN. E. A. SmitH, Minister of Lands and Mines, New Brunswick.

Hon. Jules Allard, Minister of Lands and Forests, Quebec.

HoN. G. H. Ferguson, Minister of Lands, Forests and Mines, Ontario.

Hon. Thomas H. Johnson, Attorney-General, Manitoba.

Hon. George W. Brown, Regina, Saskatchewan.

Hon. Charles Stewart, Premier, Minister of Railways and Telephones, Alberta.

Hon. T. D. Pattullo, Minister of Lands, British Columbia.

Assistant to Chairman, Deputy Head:

Mr. James White. 


\title{
Fishways in the Inland Waters of British Columbia
}

\author{
Special Need for Providing Fishways in Connection with \\ Water-power Developments in Order to Conserve \\ THE SALmon INDUSTRY
}

\begin{abstract}
THE fisheries of British Columbia, being not only on the 1 chief provincial industries, but also an. importan source of food supply, are worthy of the best efforts that can be exerted for their conservation.
\end{abstract}

In the carrying out of development works, whether for navigation, irrigation or power, provision requires to be made for the upward migration of the adult salmon for spawning purposes and for the downward passage of the young fish to the sea. Besides the salmon, other fish require consideration.

The serious consequences to the fishing resources, resulting from obstructions which prevent the free passage of salmon and other fish, have been amply demonstrated. This subject is one so vital in its bearing upon power development and yet one so frequently passed over, that it is desirable to submit the subject to special discussion; in fact, the whole question of the effect of obstructions upon the fishing industry and the efficacy of fishways as a means of overcoming the menace of such obstructions, requires thorough investigation.

Practically all of the Pacific Coast streams of British Columbia and their tributaries are annually frequented by vast numbers of Pacific salmon, consequently the salmon fishing industry is one of the most important interests to be safeguarded in the carrying out of works which will materially affect the inland waterways.

As indicating the importance of this industry, it may be cited that in the big salmon year of 1909 , canned salmon products to the value of $\$ 7,750,000$ were marketed. For the fiscal year ending March 31,1914 , which includes the 'big year' run of 1913, the marketed product was valued at $\$ 10,243,670$, while the total value of all fish marketed was $\$ 13,891,398$, or over 40 per cent of the total value of the fishery products of Canada. The 1913 salmon pack comprised over 1,350,000 cases - the largest output in the history of the industry. In the twenty years prior to 1915 the canneries of British Columbia produced an aggregate of over sixteen million cases of canned salmoneach case containing 48 pounds of dressed fish-representing a catch 
of over $200,000,000$ salmon. It is estimated that about 18,000 persons are engaged in this industry and over $\$ 8,000,000$ is invested in fishing and canning equipment.*

To better appreciate the possible effects which the construction of dams, diversion canals and other works may have upon the fishing industry, it is necessary to understand the habits of the salt-water fish which ascend the fresh-water streams.

Inves tigation the es the Pacific Salmon-the Sockeye or Blue Back salmon (Oncorhynchus nerka) Spring, Quin a Chinook or Tyee salmon (O. tschawytscha); Cohoe or Silver salmon (O. kisutch); Humpback (O. gorbusca); Dog or Chum (O. keta) - enter the streams from March to December for the purpose of depositing their ova. After spawning all the salmon die. Two of the five species, the sockeye and the spring, seek the extreme headwaters of the largest streams and there deposit their spawn. The sockeye, commercially the most important salmon, spawn in the streams tributary to the large lakes, or in the sand and gravel shoals along the shores of the lakes.

The seaward migration of the young sockeye begins in April and continues to August; they consist of two sizes, representing two ages. The smaller comprise fry $1 \frac{1}{2}$ inches in length and are hatched from eggs of the preceding autumn, while the larger fry are yearlings, which, having remained in the lakes during the first year, have attained a length of 3 to 4 inches. The spring, cohoe, humpback and dog salmon spawn in the waters of streams that are not tributary to the large lakes, and the majority of their young migrate to the sea during the following spring and summer, at which time they average $1 \frac{1}{2}$ inches. In moving downstream the young salmon hug the banks, apparently preferring the shallow water. There is, annually, an upward migration, from March to November or December, of great numbers of the adults of the five species of the Pacific salmon; and an annual down-

* For statistics relating to the fishing industry of the Province, consult the Official Year Book of British Columbia and Manual of Provincial Information for 1911, by R. E. Gosnell, pp. 203 to 226, also Annual Reports of the Commissioner of Fisheries, Victoria, B.C. The reports for 1913 to 1915 contain interesting contributions to the life-history of the sockeye salmon. Consult also article 'The Fisheries of British Columbia,' in Lands, Fisheries and Minerals, Commission of Conservation, Ottawa, 1911; also, other reports of the Commission of Conservation, Ottawa. For statement respecting 'Waters Contiguous to the Boundary Line Between British Columbia and the State of Washington,' see Report of the Joint Commission Relative to the Preservation of the Fisheries in Waters Contiguous to Canada and the United States, Ottawa, 1897, pp. 134 et seq.

$\dagger$ Many of the comments here made respecting British Columbia salmon are based upon statements kindly furnished by Mr. J. P. Babcock, Assistant Commissioner of Fisheries, B.C., and upon reports of the Provincial Fisheries Department. 
stream migration, from March to September, of two distinct ages and sizes of young salmon.

There are therefore, two main features to the problem of safeguarding the fishing interests in connection with construction work for power or other devélopment on the rivers of British Columbia. First, it is necessary to permit a sufficient number of adult salmon satisfactorily to pass all obstructions in order to reach and deposit their ova upon the spawning beds of the streams; and, second, to ensure that the young salmon are afforded a satisfactory passageway out to the sea.

Practically all the adult salmon which ascend the streams to spawn consist of fish of four or five years of age.* That is to say: the frsh which are hatched in one year do not re-ascend the stream to spawn until four or five years later. Consequently, it is not possible to evaluate the effects of an obstruction in a salmon stream until the period for return has elapsed.

Two specific instances of interference with the salmon run may be here considered.

One of the largest tributaries to the Fraser, and one of the chief salmon streams, is the Quesnel river. Quesnel lake, with its tributaries, comprises about twenty-five per cent of the entire spawning area of the Fraser river. Every four years on the Fraser river occurs what is known as the 'big year' run. This took place in 1897, 1901, 1905,1909 and 1913, and, in the normal course of events, would have been expected in 1917 .

In 1895 , the province granted to a mining company the right to construct a dam at the outlet of the Quesnel lake, but no provision was made for the passage of the salmon through the dam. The result was that, following the completion of the dam in 1898, the salmon were denied access to the spawning grounds of Quesnel lake, and, without having spawned, perished in countless thousands in the river below. Sufficient gold was not found to warrant a continuance of mining operations, and hence the gates, which had been closed for a

* The proportion of four and five-year-old fish varies between very wide limits. On the Fraser river, which is the only large stream of the Province possessing a race of sockeye which mature principally in their fourth year, about 80 per cent, on an average, are four-year-old fish. This figure is based on investigation extending over some years. On some other rivers the proportion of five-year-old fish exceeds that of four-year-old fish. Interesting details of these investigations are given in the Annual Reports of the Commissioner of Fisheries, British Columbia. 
part of two seasons, were opened. This provided sufficient water to permit the salmon to reach the head of the river, but, owing to the strong currents at the sluiceways, did not permit ingress of salmon to the lake, and hence for five years the fish continued to mass and die below the dam, while the spawning beds of Quesnel lake remained barren of sockeye salmon. In the 'big year' of 1901, the run to the Quesnel river was very large, but, owing to the failure to provide a fishway, the spawning grounds of the lake remained unseeded that year: The pack of 1905 was 500,000 cases less than in 1901, and has commonly been attributed to failure in the seeding of the beds of the Quesnel in 1901. In 1903, the Provincial Government constructed a fishway, and, in 1905, several million sockeye undoubtedly entered Quesnel lake, and the large spawning area apparently was well seeded. The run of sockeye in 1909 was believed to have exceeded that of any former year, and it has been estimated that $4,000,000$ adult sockeye salmon entered Quesnel lake through this fishway.*

In 1913 and 1914, during the construction of the Canadian Northern railway, a rock slide in the canon above Yale caused a serious blocking of the Fraser river. The slide produced currents and eddies of such character as resulted in the holding back of millions of salmon. This obstruction was more serious than that at Quesnel lake, as it affected a larger area. Reports from the various spawning grounds showed that the run reaching the grounds in 1913 was much below that of former big years. At Quesnel lake, where facilities existed for making an accurate estimate, only about 550,000 salmon passed through the fishway, as compared with $4,000,000$ in 1909.

The assistant to the Commissioner of Fisheries of British Columbia, in his report respecting conditions below the obstruction on the Fraser, stated: "The waters of the lagoon at the mouth of the Spuzzum were literally filled with sockeye, and the stream itself was also crowded for the mile and one-half of its length to the falls,....Fora distance of three miles and a half, from the Skuzzy rapids to Hell'sgate below, the surface of all the eddies and the slack waters were covered with sockeye," $† \ldots$.

* Annual Report of the Commissioner of Fisheries, British Columbia, 1909, pp. 1-13.

+ See 'Report on the Obstructed Condition of the Fraser River at Skuzzy Rapids, China Bar, Hellgate and White Creek,' in Report of the Commissioner of Fisheries, British Columbia, 1913, p. R39; also pp. R20 et seq; also Report for 1914, p. N20. 
The effect of this obstruction during 1913-14 will not be fully known until after the runs of 1917-18, but it appears safe to predict that the results will be found to be of a very serious character.*

Sufficient has now been said to prove the great importance of providing satisfactory ingress and egress for the salmon. At the present time the salmon that escape capture on the fishing grounds have, save for natural obstructions, such as are caused by falls too steep to be surmounted, an unobstructed passage-way from the sea to the remotest sections of the water-sheds of the large streams; there are, moreover, practically no canals diverting from the main channels. It is absolutely essential for the life of the salmon industry in British Columbia that adequate and practically workable provisions be made and maintained for the safeguarding of the salmon-both adult and young -in connection with the granting of any rights or privileges for the damming of streams, for the diversion of water for power, irrigation, or other activities involving the use of the inland waters.

It is not possible here, nor is it the intention, to enter upon an extended discussion of the ways and means by which the integrity of inland waters may be preserved for the propagation of fish life. It is, however, necessary to direct special attention to the need of providing and maintaining a class of structure which has been altogether too much neglected, viz., fishways.

An excellent summary, respecting the general principles that should find exemplification in the construction of fishways, is contained in a statement prepared by the architect and engineer of the United States Board of Fisheries:

"With the development in late years of water-power for commercial enterprises on an economic basis, with the construction of canals for cheapening the transportation of freight, with the proposition of irrigating the otherwise waste lands of the country-all of which improvements call for the erection of dams across our rivers - the steady decrease of fish life in the waters above said dams or other obstructions has become more and more apparent, and the question has presented itself how to enable the fish to ascend to the headwaters of rivers, in order to reach their spawning grounds for the propagation of their kind, or to follow their migra tory habits in search of food as heretofore. This question is being best met by the construction of suitable fishways.

* Information has come to hand indicating the character of the salmon run of 1917 , and the indications appear clearly to justify the apprehension entertained in 1913 respecting the serious results caused by the rock slide, and which results, it was held, would later be manifested. 
"The underlying principle in the construction of fishways is the retardation of the current velocity of a waterfall so as to enable fish to surmount it. Innumerable devices with that end in view have been invented and proved more or less successful. Certain physical conditions in the location and a proper method of construction are the important factors.

"Of the physical conditions, the two principal ones are (1) accessibility of the fishway free from disturbance, its outlet being located in a pool at the bottom of the falls where fish would naturally pass in ascending the river, and (2) an abundant discharge of water through the outlet so as to attract the fish. It is to be noted that fish as a rule do not ascend rivers at low-water stage, but between mean and high water, and preferably during sunshine and warm weather.

"In style of construction fishways may be classed in four systems:

"I. The inclined plane system, in which a series of baffle or deflecting plates are so arranged in an inclined flume as to cause the water to follow in its descent a long sinuous route.

"II. The pool and fall or step system, in which the water is brought down to a lower level by a series of short falls with intervening pools.

"III. The counter current system, in which the-descending volume of water is being checked by meeting a current opposing it at certain intervals.

"IV. The lock and gate system, in which a higher or lower level is reached through one or more locks operated by gates.

"In all four systems of fishways certain general rules governing the construction must be observed.

"1. The slope of a fishway built on the inclined plane system should not be steeper than 1 foot vertical to 10 feet horizontal; the pool and fall system, as well as the counter current system, should not have a slope of more than 1 vertical to 4 horizontal, so as to insure a current velocity of not exceeding 10 feet per second in any portion of the fishway. The lock and gate system deals merely with a vertical lift. The width of a fishway somewhat governs the slope, and the wider the fishway the more gradual the slope should be.

"2. The available volume of water and the size of the fish must be considered in the dimensions adópted for the fishway; small fish, like herring, bass, trout, etc., may not require over 6 inches in the clear at the narrowest points or openings in the fishway, while for large fish, like shad, rockfish, salmon, etc., the clearance spaces should not be less than 9 inches in any direction.

"3. A fishway for small fish does not need to be more than 2 feet wide by about 1 foot deep, while that for large fish ought to have a least width of 4 feet with a depth correspondingly large.

"4. Plenty of light should be admitted in a fishway, both for 
maintaining therein the natural conditions of the water, and in order that the interior may easily be inspected and any foreign matter removed.

"5. A fishway in all its parts should, by the action of the current of water passing through it, be as nearly as possible, self-cleaning of all sand, gravel, mud, and rubbish.

"6. The water supply of a fishway should be ample and the same, or nearly so, at both ordinary high and low water stages, avoiding thereby any regulating gates or other devices calling for the services of an attendant.

"7. The top and sides of a fishway should be above ordinary high water.

"8. The fishway should be built very strong and be well protected against the destructive effects of freshets, drift logs, ice, etc.

"9. The intake and outlet should be well submerged and the former protected against floating debris, etc., by a suitable grating.

"The location of a fishway must be such that ascending fish will not be alarmed and driven off by disturbance from boats, fishermen, etc.

"The material of fishways may be wood, stone, concrete, or iron, depending opon the construction of the dam, its size, the topography and nature of the site, the labour and material at hand, and the funds available."*

It is not the intention here to discuss the merits of various fishways, but it is desired most emphatically to point out that great difficulty will be experienced in providing and maintaining satisfactory fishways in power dams of considerable height, say above 25 or 30 feet.

The United States Bureau of Fisheries is alive to the fact that the fisheries of the country have suffered by reason of inadequate provision being made for the fish to overcome obstructions in streams. With commendable enterprise the Bureau had commenced an extensive investigation involving observations and experiments to determine the efficiency of all fishways now in use. The research, owing to present exigencies, has been temporarily suspended.

The Bureau appears to have accepted as a basic doctrine, where matters of advantage or disadvantage are being considered in connection with dams and the construction and maintenance of fishways, that any benefit of doubt should properly be given to the fish; and,

* Consult Fishways, by H. Von Bayer, C.E., a paper presented before the Fourth International Fishways Congress, held at Washington, U.S.A., Sept. 22-26, 1908. 
further, the Bureau maintains that if fish of known migratory habit are present and, presumably, obstructed to such a degree as to make a fishway desirable, the asserted impracticability of fishway construction is not to be accepted from anyone without strong affirmative evidence.

This Bureau has stated that it has no knowledge of fishways in the United States that successfully pass salmon over dams more than 20 feet in height, and that doubtless there are few fishways really successful for dams over 12 feet in height, even for the salmon.*

The State of Washington, bordering British Columbia on the south, has experienced difficulty in providing suitable fishways. In this State, conditions on many of the salmon streams are similar to those in British Columbia, and power dams have been constructed 100 feet or more in height. It is instructive to note the experience and conclusion of the Department of Fisheries and Game of the State of Washington, as communicated in a letter by the State Fish Commissioner and Chief Game Warden, Mr. L. H. Darwin. Mr. Darwin comments upon the difficulties of providing satisfactory fishways in very high dams, but entertains hope that the difficulties may yet be solved and fishways satisfactory in operation be devised.

It has been found that a fishway is practically useless unless its entrance is where the fish can easily find it, and, in order to bring the entrance to the fishway into the waters at the foot of a high dam, it is usually necessary to curve the fishway. Such a fishway is an expensive matter, concrete construction being, for high dams, the only really satisfactory method, and the best rule laid down does not permit

* The United States Bureau of Fisheries has stated that it lacks information respecting the efficient operation of any existing fishway in the United States at dams more than 20 feet in height. It is claimed, however, that fish have, by means of fishways, satisfactorily surmounted dams $\mathbf{4 0}$ feet or more in height. The Bureau has kindly furnished a memorandum of some of the instances for which such claim is made. These, as reported by Mr. Carl D. Shoemaker, game warden of the State of Oregon, are as follows:

"A ladder giving excellent satisfaction is located in the Dee river, Hood River county. This ladder has been used entirely by trout, principally of the cutthroat variety. It is about two hundred feet long and rises about fifty feet.

"At the Ray Gold dam, on the Rogue river, we have another ladder about forty feet high, which is used also by salmon and steelheads. The fish pass over the ladders in the Rogue river very easily."

As reported by John J. Lenihan, Fish Commissioner of the State of Wyoming: "The only one (fishway) that seems to successfully pass fish over a dam is located in Snake river, near Jackson lake. This dam is about fifty feet high. Fish can be observed passing over it during the months of June and July, same being of the blackspotted species."

A fishway, which is stated by Mr. T. Rouault, Jr., Game and Fish Warden of New Mexico, to work very successfully, is located at the reservoir owned by the Santa Fe Light and Power Company, on the Santa Fe river. The height of the dam was not given. 
a fall of more than one foot in ten for the inclined plane system or one in four in the pool and fall system, which latter must be adopted for high dams. Another point to be taken into consideration is the immense amount of strength which the fish must possess to make a long ascent. In the natural streams they have pools or eddies in which they can rest; and even though an attempt is made to reproduce these in the fishways, it is questionable if they are as satisfactory as in the natural streams. In order to provide better facilities for safeguarding the fishing interests than are afforded by fishways for high dams the Department of Fisheries and Game of the State of Washington permits and encourages owners of high dams to build a hatchery at the foot of the dams instead of constructing a fishway. This is in accordance with the established policy of the state, to acquire a hatchery on every salmon stream.

In Canada, both Federal and Provincial legislation has been enacted to safeguard the inland fisheries and to provide for the construction of fishways. The chief difficulty, however, as far as fishways are concerned, is that too frequently proper fishways are not provided, and that such as are provided are allowed to fall into disuse. The Dominion Fisheries Act* explicitly provides that fishways shall be built wherever the Minister of Marine and Fisheries determines they are necessary. $\nmid$ It says:

"1. Every slide, dam or other obstruction across or in any stream, where the Minister determines it to be necessary for the public interest that a fish-pass should exist, shall be provided by the owner or occupier with a durable and efficient fishway, or canal around the slide, dam or other obstruction, which shall be maintained in a good and effective condition by said owner or occupier, in such place and of such form and capacity as will, in the opinion of the Minister, satisfactorily permit the free passage of fish through the same. R.S., s. 46.

"2. The place, form and capacity of the fishway or canal shall be prescribed by any fishery officer by notice in writing. R.S., s. 46, ss. 2.

“3. Every fishway and canal shall be kept open and unobstructed and shall be supplied with such sufficient quantity of water as the Minister considers necessary to enable the fish frequenting the waters in which such fishway or canal is placed to pass through the same

* The Fisheries Act, 1914, R.S., c. 45, s. 1.

† The Assistant Commissioner of Fisheries in British Columbia, Mr. John P. Babcock, has had an excellent fishway, approximating as nearly as practicable to the conditions of nature, cut in the rock at the side of the falls on the Meziadin river, Nass River watershed. The cost of this fishway was defrayed by the Dominion Department of Marine and Fisheries. See 'The Fishway at Meziadin Fall,' in the Report of the Commissioner of Fisheries, British Columbia, for 1913, pp. R51-52. 
during such times as are specified by any fishery officer. R.S., s. 46, ss. 3 .

"4. The Minister may authorize the payment of one-half of the expense incurred by such owner or occupier in constructing and maintaining any fishway or canal; and after a fishway or canal which has been duly approved by the Minister has been built at the cost of the owner or occupier of any slide, dam or other obstruction, or after such owner or occupier has paid one-half the cost thereof and such fishway or canal there after proves to be ineffective, the total cost of any change in such fishway or canal or any new fishway or canal required to enable the fish to pass by such slide, dam or other obstruction, shall be paid by His Majesty. R.S., s. 46, ss. 4 .

“5. The Minister, in order to procure the construction of any fishway or canal, pending proceedings against any owner or occupier for the penalty imposed by this Act, may make and comple te the same forthwith, and may authorize any person to enter upon the premises with the necessary workmen, means and materials for such purpose, and may recover from the owner or occupier the whole expense so incurred by action in the name of His Majesty. R.S., s. 46, ss. 5 .

"6. Where unused slides, dams, obstructions, or any thing detrimental to fish exist, and the owner or occupier thereof does not, after notice, given by the Minister, remove the same, or the owner is not resident in Canada, or his exact place of residence is unknown to the Minister, the Minister may, without being liable to damages, or in any way to indemnify the said owner or occupier, cause said slide, dam, obstruction, or thing detrimental to fish life to be removed or destroyed and in cases where notice has been given to the owner or occupier, may recover from said owner or occupier the expense of so removing or destroying the same."

The British Columbia Water Act, 1914, Section 35, states: "Proper provision shall be made by every licensee to the satisfaction of the Comptroller....for the erection and maintenance by the licensee of a durable and efficient fishway in the stream or other waterway affected by the works."

Suitable fishways require comparatively little water. The periods during which they should be kept full vary somewhat with the habits of the fish. The fishway season does not coincide with the low-water season of the winter months and hence in this respect conflicts comparatively little with power development.

While in this discussion reference has been made specifically to the salmon in connection with the streams of the Pacific drainage basin, it should be borne in mind that other fish of migratory habit require consideration where dams might seriously interfere with their passage. In addition to the salmon, there are trout, sturgeon, shad, 
common eel, smelt, striped bass, eulachon and lampreys, and possibly suckers and large fish of the carp and minnow family, which also, require consideration.

The absence of suitable and efficient fishways, properly maintained, is a very decided loss to the fisheries of any province, and more especially, perhaps, is this true in the case of salmon fisheries. It may be commented that the loss viewed solely from the standpoint of the tourist traffic may be a serious one. Baedeker's Guide says that "every salmon caught by tourists in the Maritime Provinces involves expenditure in the country of from $\$ 25$ to $\$ 35 . "$

Respecting the maintenance of an unobstructed passageway for the seaward migration of the young salmon the problem is different.

As yet no practical device has been found that will satisfactorily prevent young fish from entering irrigation ditches and canals leading to power plants. Even the clearest streams carry an amount of vegetable matter and debris sufficient to clog any screen having mesh small enough to prevent the passage of young salmon. Fish passing into irrigation canals are, of course, eventually destroyed.

In the case of power plants, the problem varies with the character of the development. If a direct fall, in a state of nature, was sufficient, to hold back the salmon, it might not be always necessary, when a dam is constructed, to make provision for the salmon, per se, unless it be desired to open up new spawning grounds. Where the power development is a low head proposition, means for the passage of the young fish downstream may be provided without serious difficulty. The fish may in many instances, without hurt, pass over the spillways if sufficient water is flowing over same, but otherwise special means of passage will be necessary.

A more difficult problem is presented in connection with high head developments. If a low intake dam is utilized, and there is, at the proper season of the year, ample water flowing over the spillways, probably the young fish will pass downstream without hurt; and, with a suitable arrangement for the intake, few, if any, will pass into the power flumes. If, however, the head is concentrated by a high dam, or the intake dam constitutes a storage dam where little water is wasted-all passing through the power turbines-the young fish certainly would not survive a journey through the contracted passages of high head turbines. The amount of risk incurred by the fish in passage over a spillway of a high dam would, of course, depend upon its character. An ameliorating condition lies in the fact that the bulk 
of the young salmon descend the streams at times of high water, when usually there is ample water passing over the spillways. There is need for further investigations of this problem.

Water-power development may also conflict with fishing interests by the destruction of spawning grounds through the manipulation of the levels of lakes used as storage reservoirs. When lake levels are raised the margin of the lake, up to the proposed flowage line, should be stripped of tree growth and underbrush to facilitate the formation of new beaches and maintain the healthy condition of the water. Here again, the question of clearing becomes one of weighing advantages and disadvantages, but it is doubtful if any of the supposed advantages derivable from power development will offset the destruction of the source of one of our important supplies of food. Certainly, with intelligent regulation and forceful administration, the streams of the Province should not only continue to produce vast numbers of salmon, but the supply may be greatly increased. In fact, our supplies must be increased. Recording their conclusions, some of the members of the special committee appointed to investigate the fishing industry of the State of Washington report:

"We find that civilization, and all of the activities of civilization, have a very serious effect in diminishing the natural propagation of fish. We find that young fish that are hatched in rivers tributary to irrigation ditches, in their journey to the sea are led, to a large extent, into irrigation canals and are thus destroyed. We find also that the sawdust from the mills, both in salt and fresh waters, is destructive of the young salmon and to the salmon eggs, and that various other agencies of modern civilization tend to the destruction of the young fish before they reach their maturity."*

In view of the facts above presented, it is evident that no development for power or irrigation should be permitted on any of the salmon streams without fully safeguarding the fishing industry.

* Annual Reports of the State Fish Commissioner, State of Washington, Department of Fisheries and Game, 1911-1912, pp. 36. 





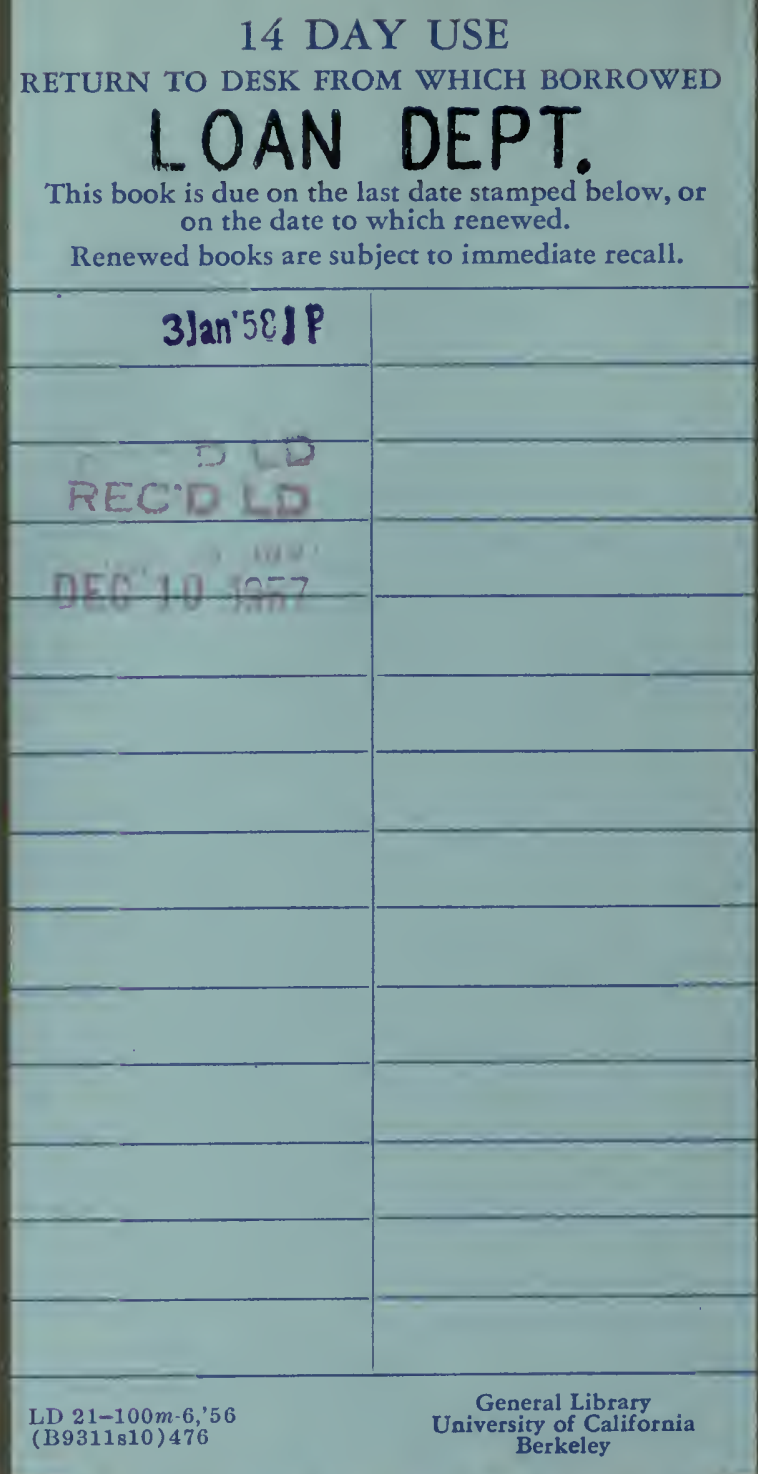


Photomount

Pamphlet

Binder

Gaylord Bros., Inc. Makers

Stockton, Calif. PAI. AAK. 21, 1908

THE UNIVERSITY OF CALIFORNIA LIBRARY 
* 1 in

(1) 1

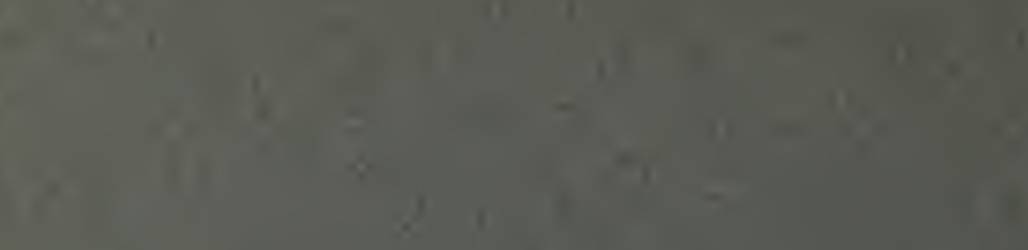

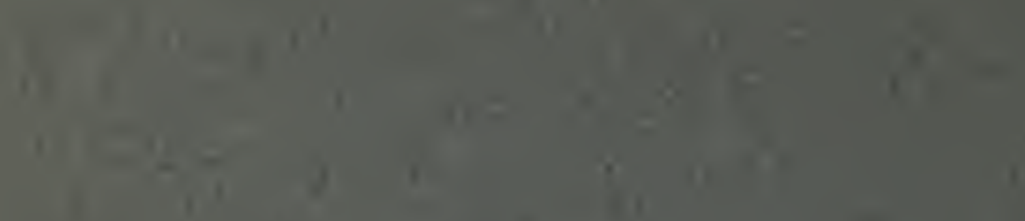

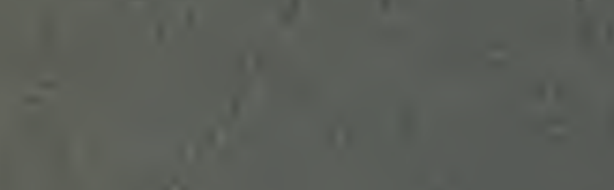

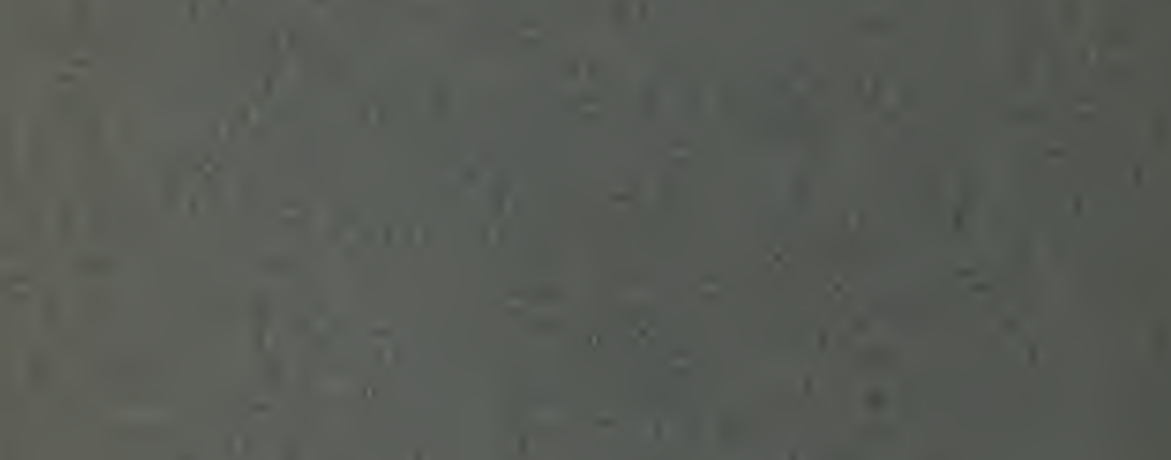

$$
\begin{aligned}
& \operatorname{lin}_{11} \\
& \text { (7) }
\end{aligned}
$$$$
x^{2}=x+2 x+2
$$$$
1
$$

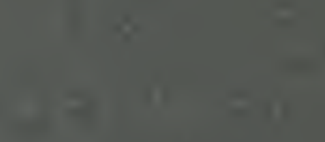

$$
\begin{aligned}
& \text { s. }=
\end{aligned}
$$$$
x^{1}-=
$$$$
\text { a. } 1-1=
$$$$
=-1-1+2
$$
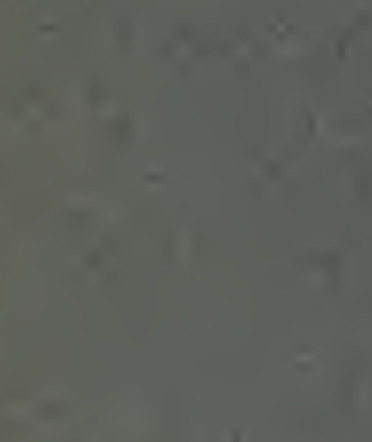

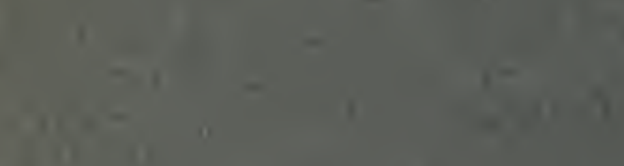

$$
\begin{aligned}
& +x= \\
& \text { - }
\end{aligned}
$$$$
\text { i }
$$

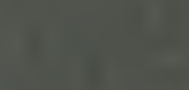

